\title{
EKSPERIMENTASI MODEL KOOPERATIF CIRC DAN JIGSAW UNTUK PENINGKATAN KETERAMPILAN MEMBACA DITINJAU DARI KEMAMPUAN LOGIKA BERBAHASA
}

\author{
Murtono \\ Email : muris66@yahoo.co.id \\ PGSD FKIP Universitas Muria Kudus
}

\begin{abstract}
The background of this study is a fact that the reading skill of elementary school students in Indonesia, especially in Central Java is still low. One of the causes of the low level of reading skill deals with teaching models implemented by teachers which are still relatively traditional (direct method) so that students cannot be active, creative, effective, innovative and happy. Additionally, the skill of language logic ability is not directly involved. Based on the reason above, the researcher has done an experiment on the implementation of cooperative learning model of CIRC and Jigsaw toward reading skill viewed from language logic skill which aims at : 1) finding out the difference of reading skill between the students of bahasa Indonesia who join in CIRC cooperative learning model and Jigsaw cooperative learning model; 2) finding out the difference of reading skill between the students who have high language logic ability and low language logic ability; 3.) and finding out the interaction between the use of the two cooperative learning models and the language logic ability in influencing the reading skill.

The study was an experimental research with $2 \times 2$ factorial design. Manipulation was done towards the learning model variables. The experiment group was given a special treatment of respectively CIRC and Jigsaw learning model. The experiment group was divided into two categories, students who had high language logic ability and those who had low language logic ability. The population of the study was the fifth grade elementary school student in Central Java of 2011/2012 Academic Year. Whereas, the sample was the fifth grade elementary students of 12 Elementary Schools in four regencies/cities, those are 2 Elementary Schools in Kudus Regency, 2 Elementary Schools in Semarang City, 2 Elementary Schools in Magelang Regency, and 2 Elementary Schools in Karanganyar Regency, which totally as many as 246 students taken by multi stage area random sampling technique. The data collection of reading skill was done by using test of reading skill, while assessment on the level of language logic ability was done by using test of language logic ability. After the data was collected, they were presented in form of tables and graphs, which were then analyzed. The technique of data analysis was two way variant analysis.

There are two primary in the study. First, the reading skill of the students who joined in CIRC learning model is better than those who joined in Jigsaw model. Second, the reading skill of the students who have high language logic ability is better than those who have low language logic ability. Third, there are interactions between the use of cooperative learning model and the language logic ability in influencing reading skill. The interactions are to be used for students who have high language logic ability, CIRC learning model is more effective compared with Jigsaw. To be used the use students who have low language logic ability, models of CIRC or Jigsaw, does not show an effectiveness difference.
\end{abstract}

Keywords : model CIRC and Jigsaw, reading skill, language logic ability

\begin{abstract}
ABSTRAK
Penelitian ini dilatarbelakangi oleh keterampilan membaca siswa sekolah dasar di Indonesia umumnya dan di Jawa Tengah khususnya yang masih di bawah rata-rata masyarakat dunia. Kerendahan keterampilan membaca ini salah satunya disebabkan oleh model pembelajaran yang diberikan oleh guru yang masih relatif trasidional (pembelajaran langsung) sehingga siswa tidak melakukan pembelajaran aktif, kreatif, efektif, inovatif, dan menyenangkan. Di samping itu, di dalam pembelajaran juga tidak secara langsung dilibatkan kemampuan logika berbahasa siswa. Berpijak dari
\end{abstract}


kondisi inilah peneliti melakukan eksperimen penerapan model pembelajaran kooperatif CIRC dan Jigsaw terhadap keterampilan membaca ditinjau dari kemampuan logika berbahasa, yang bertujuan untuk menemukan perbedaan keterampilan membaca bahasa Indonesia siswa antara: (1) yang mengikuti pembelajaran dengan model pembelajaran kooperatif $C I R C$ dan yang mengikuti model kooperatif Jigsaw. (2) yang memiliki kemampuan logika berbahasa tinggi dan yang rendah, (3) dan menemukan interaksi antara penggunaan kedua jenis model pembelajaran kooperatif dan kemampuan logika berbahasa dalam mempengaruhi keterampilan membaca.

Penelitian ini adalah penelitian eksperimental dengan desain faktorial $2 \times 2$. Manipulasi dilakukan pada variabel model pembelajaran. Kelompok eksperimen diberikan perlakukan khusus, masing-masing model pembelajaran CIRC dan Jigsaw. Pada kelompok eksperimen dibedakan atas siswa yang memiliki kemampuan logika bahasa tinggi dan siswa yang memiliki kemampuan logika bahasa rendah. Populasi penelitian ini adalah siswa kelas 5 sekolah dasar di Jawa Tengah tahun pelajaran 2011/2012, sedangkan sampel adalah siswa kelas 5 pada 8 SD di empat kabupaten/kota, yaitu 2 SD di Kabupaten Kudus, 2 SD di Kota Semarang, 2 SD di Kabupaten Magelang, dan 2 SD di Kabupaten Karanganyar, yang keseluruhannya berjumlah 246 siswa yang diambil dengan teknik multi stage area random sampling. Pengumpulan data keterampilan membaca dilakukan dengan tes keterampilan membaca, penentuan tingkat kemampuan logika berbahasa dilakukan dengan tes kemampuan logika berbahasa. Setelah data terkumpul disajikan dalam bentuk tabel dan grafik, selanjutnya dilakukan analisis. Teknik analisis data yang digunakan adalah analisis variansi dua jalan.

Terdapat tiga kesimpulan utama dan kesimpulan hasil interaksi dalam penelitian ini. Pertama, keterampilan membaca kelompok siswa yang mengikuti pembelajaran dengan model pembelajaran CIRC lebih baik daripada yang belajar dengan model Jigsaw. Kedua, keterampilan membaca kelompok siswa yang memiliki kemampuan logika bahasa tinggi lebih baik daripada kelompok siswa yang memiliki kemampuan logika bahasa rendah. Ketiga, terdapat interaksi antara penggunaan jenis model pembelajaran kooperatif dan kemampuan logika berbahasa dalam mempengaruhi keterampilan membaca. Interaksi tersebut berupa: siswa yang memiliki kemampuan logika tinggi model CIRC lebih efektif digunakan dibandingkan Jigsaw. Sedangkan untuk siswa yang memiliki logika bahasa rendah ketiga model sama efektifnya.

Kata kunci : model CIRC dan Jigsaw, keterampilan membaca, kemampuan logika berbahasa

\section{PENDAHULUAN}

Membaca merupakan keterampilan yang menjadi jendela ilmu pengetahuan. Hampir semua ilmu pengetahuan dipahami melalui membaca. Oleh karena itu, perkembangan ilmu pengetahuan dan teknologi menuntut terciptanya masyarakat untuk gemar membaca. Masyarakat yang demikian akan memperoleh pengetahuan lebih cepat dan wawasan baru yang semakin meningkatkan kecerdasannya sehingga mereka lebih mampu menjawab tantangan hidup pada masa-masa mendatang (Farida Rahim, 2003: 1). Berkaitan dengan keterampilan membaca, masyarakat Indonesia dikatakan sebagai bangsa yang belum mempunyai kebiasaan dan budaya baca yang baik, sehingga keterampilan membaca mereka pun kurang memadai. Kekurangterampilan membaca masyarakat Indonesia ini, salah satunya terbukti dari rendahnya tingkat kegemaran ataupun keterampilan membaca pelajar Indonesia. Sebagaimana yang disampaikan oleh Asia Weeks (dalam Iskandarwassid dan Sunendar, 2009: 245-246), fakta di lapangan menunjukkan bahwa masyarakat negara maju ditandai oleh telah berkembangnya budaya baca. Sebaliknya negara-negara yang sedang berkembang ditandai dengan rendahnya budaya baca. Rendahnya keterampilan membaca ini disebabkan oleh beberapa faktor, antara lain lemahnya motivasi siswa, kurangnya koordinasi antarpengajar, dan terutama kurang adanya analisis kebutuhan siswa dalam penyusunan materi pembelajaran membaca (A. Chaedar Alwasilah, 2000: 677). Kemampuan siswa untuk memahami aspek kebahasaan sebenarnya cukup baik, namun apabila diminta untuk mengaplikasikan pemahaman membaca, para siswa ini malas menjalankan dan mengalami kesulitan. Senada dengan ini, Sumardi (2000: 787) menyatakan waktu yang tersedia untuk pengajaran bahasa habis tersita untuk menjelaskan dan menghafalkan kaidah tata bahasa.

Sehubungan dengan kondisi di atas, perlu dilakukan eksperimen dalam proses pembelajaran keterampilan membaca dengan model pembelajaran yang berpilar PAKEM (Pembelajaran Aktif, Kreatif, Efektif, dan Menyenangkan), yaitu pembelajaran kooperatif. Model pembelajaran kooperatif 
ini dikembangkan khususnya bagi siswa SD karena memberikan motivasi dan harapan kepada siswa dengan memberikan pembelajaran yang menyenangkan, mengulang-ulang, dan sesuai kebutuhan . Di samping itu, bagi anak usia ini peran kelompok sebaya sangat berarti. Ia sangat mendambakan penerimaan oleh kelompoknya. Baik dalam penampilan perilaku ataupun dalam ungkapan diri, terutama bahasa, ia cenderung meniru kelompok sebayanya (Iskandarwassid dan Sunendar, 2009: 140). Keadaan ini sangat selaras dengan napas model pembelajaran kooperatif yang dasar pijakannya mengutamakan kerja sama dalam pembelajarannya. Model pembelajaran kooperatif memiliki dasar filosofis bekerja sama akan menghasilkan energi kolektif yang disebut sebagai sinergi (synergy). Sinergi ini akan menghasilkan sesuatu yang luar biasa Dalam dunia pendidikan sinergi ini diaplikasikan dalam komunitas pembelajaran (Johnson, R.T. \& Johnson, D.W. 1994: 21; Slavin, 1995: 16; Joyce, 2009: 34).

Pokok bahasan yang dikaji dalam penelitian ini adalah eksperimentasi model pembelajaran kooperatif CIRC dan Jigsaw terhadap keterampilan membaca bahasa Indonesia ditinjau dari kemampuan logika berbahasa bagi siswa sekolah dasar di Dinas Pendidikan Nasional Provinsi Jawa Tengah. Adapun masalah pokok dirumuskan: (1) Sejauh mana efektivitas model pembelajaran kooperatif jenis CIRC dan Jigsaw untuk peningkatan keterampilan membaca bahasa Indonesia?, (2) Apakah ada perbedaan keterampilan membaca bahasa Indonesia antara kelompok siswa yang memiliki kemampuan logika berbahasa yang tinggi dan yang memiliki kemampuan logika berbahasa yang rendah?, dan (3) Apakah ada interaksi antara penggunaan jenis model pembelajaran kooperatif dan kemampuan logika berbahasa dalam mempengaruhi keterampilan membaca?

Penelitian ini memiliki tujuan: (1) Menemukan efektivitas penerapan model pembelajaran kooperatif jenis CIRC dan Jigsaw untuk peningkatan keterampilan membaca bahasa Indonesia, (2) Menemukan perbedaan keterampilan membaca bahasa Indonesia antara kelompok siswa yang memiliki kemampuan logika berbahasa tinggi dan yang memiliki kemampuan logika berbahasa rendah, dan (3) Menemukan interaksi antara penggunaan kedua jenis model pembelajaran kooperatif dan kemampuan logika berbahasa dalam mempengaruhi keterampilan membaca.

Orientasi di dalam pembelajaran bahasa pada dasarnya ialah empat keterampilan berbahasa. Apabila keempat keterampilan berbahasa ini dapat terkuasai dengan memadai oleh seseorang, maka dianggap baiklah keterampilan berbahasa seseorang itu. Keempat keterampilan yang dimaksud adalah keterampilan menyimak, keterampilan berbicara, keterampilan membaca, dan keterampilan menulis. Keempat keterampilan ini saling berkait dan menunjang satu dengan yang lainnya. Keempatnya merupakan keterampilan yang berbeda tetapi korelatif, tidak ada keterampilan menyimak tanpa berbicara atau membaca, tidak ada keterampilan berbicara tanpa menyimak, tidak ada keterampilan membaca tanpa menulis, tidak ada keterampilan menulis tanpa membaca, dan sebagainya. Demikianlah keempatnya saling erat berkait. Namun demikian, untuk memudahkan pembelajarannya, keempatnya perlu didalami secara mandiri. Ini dilakukan semata-mata untuk memudahkan pendalaman pembelajarannya.

Harimurti Kridalaksana (2009: 151) mengartikan membaca adalah menggali informasi dari teks, baik dari yang berupa tulisan maupun dari gambar atau diagram, maupun dari kombinasi itu semua. Membaca merupakan keterampilan mengenal dan memahami bahasa tulisan dalam bentuk urutan lambang-lambang grafis dan perubahannya menjadi wicara bermakna dalam bentuk pemahaman diam-diam atau pengujaran keras-keras. Kirby dalam Encyclopedia of Language and Literacy Development (2007: 1) mendefinisikan membaca adalah proses seseorang memahami teks yang dibaca, dengan tujuan apa, mengapa diajarkannya, dan mengapa peduli dengan hal tersebut. Klein (1991: 22) mengemukakan bahwa membaca mencakup (1) membaca merupakan suatu proses, (2) membaca adalah suatu strategis, dan (3) membaca merupakan interaktif. Membaca merupakan suatu proses, dimaksudkan informasi dari teks dan pengetahuan yang dimiliki oleh pembaca mempunyai peranan yang utama dalam membentuk makna. Membaca adalah suatu strategis, mengandung makna keefektifan membaca ditentukan oleh penggunaan berbagai strategi membaca yang sesuai dengan teks dan konteks dalam rangka mengkontruksi makna ketika membaca. Strategi ini bervariasi sesuai dengan jenis teks dan tujuan membaca. Sedangkan membaca merupakan interaktif mengandung makna keterlibatan pembaca dengan teks tergantung pada konteks. Orang yang senang membaca suatu teks yang bermanfaat, akan menemui beberapa tujuan yang ingin dicapainya, teks yang dibaca seseorang harus mudah dipahami sehingga terjadi interaksi antara pembaca dan teks. 
Secara umum pada dasarnya membaca mencakupi dua aspek, yakni aspek mekanik dan aspek pemahaman. Aspek mekanik atau visual berkaitan dengan kemahiran membaca dalam menggerakkan dan memanfaatkan organ wicara lainnya pada waktu membaca. Sedangkan aspek pemahaman berhubungan dengan kemahiran pembaca dalam menangkap isi bacaan yang dibaca. Pemahaman terhadap bacaan lebih diutamakan.

Berkaitan dengan membaca pemahaman, para ahli memberi beberapa cakupan keterampilan dalam membaca pemahaman. Crawley dan Mountain (1995: 14) mengatakan sebagai suatu proses berpikir, membaca mencakupi aktivitas pengenalan kata, pemahaman literal, interpretasi, membaca kritis, dan pemahaman kreatif. Nurhadi (2004: 57) menjelaskan bahwa pemahaman dalam membaca berhubungan dengan kemahiran pembaca dalam menangkap isi bacaan, yaitu kemampuan membaca literal, kemampuan membaca kritis, dan kemampuan membaca kreatif. Ahli lain, menyatakan bahwa membaca sebagai sesuatu yang merujuk pada proses memahami makna, proses memahami ini melalui berbagai tingkat, mulai dari tingkat literal sampai pada pemahaman interpretatif, kreatif, dan evaluatif (Imam Syafei, 1999: 22).

Sementara itu, Brown (2004: 189) mengatakan bahwa membaca pemahaman meliputi beberapa jenis, yaitu membaca perseptif, membaca selektif, membaca interaktif, dan membaca ekstensif.

Berpijak dari beberapa batasan di atas, dapat ditarik suatu kejelasan bahwa keterampilan membaca pemahaman pada hakikatnya mencakupi lima jenis pemahaman, yakni pengenalan kata, pemahaman literal, interpretatif (evaluatif), membaca kritis, dan membaca kreatif. Pengenalan kata adalah keterampilan pembaca untuk mengenal bahan bacaan yang tertera secara tersurat. Pembaca hanya menangkap informasi yang tercetak dengan jelas dalam bacaan yaitu merujuk kata-kata dan kalimat dalam wacana yang kemudian mengingatnya dalam pikiran. Pengenalan kata bisa berupa aktivitas membaca kata-kata dengan menggunakan kamus (Crawley dan Mountain, 1995: 31). Membaca literal adalah keterampilan pembaca untuk menangkap dan memahami bahan bacaan yang tertera secara eksplisit. Eksplisit artinya pembaca hanya menangkap informasi yang tercetak secara tampak jelas dalam bacaan. Ciri-ciri keterampilan membaca ini adalah tidak melibatkan berpikir kritis, hanya menerima apa adanya dan mengasosiasikan kembali tentang apa yang dikatakan penulis, bersifat pasif, pemahaman hanya pada aspek yang tersurat, hanya dapat menjawab pertanyaan: apa, siapa, kapan, di mana, dan bagaimana seperti apa yang disampaikan pengarang (Nurhadi, 2004: 5758). Membaca interpretatif adalah keterampilan pembaca untuk menangkap dan memahami bahan bacaan yang tersirat. Pemahaman ini diperoleh melalui kesan, pendapat, dan pandangan yang berhubungan dengan adanya tafsiran. Siswa diminta mengapresiasi teks dengan reseptif, sesuai dengan penafsiran masing-masing asal logis dan memiliki dasar yang dapat dipertanggungjawabkan (Pressley, 2001: 5; Imam Syafei, 1999: 36). Membaca kritis adalah keterampilan pembaca mengolah bahan bacaan secara kritis untuk menemukan keseluruhan makna bahan bacaan, baik makna yang tersurat maupun yang tersirat. Kegiatan ini dilakukan melalui tahapan mengenal, memahami, menganalisis, menyintesis, dan mengevaluasi (Nurhadi, 2004: 59-60).Membaca kreatif yaitu keterampilan membaca, yang tidak hanya menangkap makna yang tersurat ataupun makna tersirat, lebih dari itu juga mampu secara kreatif menerapkan hasil membacanya untuk kepentingkan seharihari. Indikator seseorang yang memiliki keterampilan membaca kreatif adalah terampil menerapkan hasil membaca untuk kepentingan sehari-hari, terjadi perubahan sikap dan tingkah laku setelah proses membaca selesai, hasil membaca berlaku dalam waktu yang lama, dan terampil menilai secara kritis dan kreatif bahan bacaan serta memberikan umpan balik (Crawley dan Mountain, 1995: 31; Farida Rahim, 2003: 27).

Dasar filosofis pembelajaran kooperatif ialah bekerja sama akan menghasilkan energi kolektif yang disebut sebagai sinergi (synergy). Sinergi ini akan menghasilkan sesuatu yang luar biasa. Dalam dunia pendidikan sinergi ini diaplikasikan dalam komunitas pembelajaran (Johnson, R.T. \& Johnson, D.W. 1994: 21; Slavin, 1995: 16; Joyce, 2009: 34).

Di samping dasar filosofis di atas, model pembelajaran kooperatif muncul karena adanya suatu anggapan mengenai tabiat dasar manusia sebagai makhluk sosial dan cara-cara mereka belajar. Model sosial menitikberatkan pada tabiat sosial manusia, bagaimana manusia mempelajari tingkah laku sosial, dan bagaimana interaksi sosial ini dapat meningkatkan hasil capaian pembelajaran. Oleh karena itu, tujuan utama pendidikan yang ingin dicapai dalam model ini adalah untuk mempersiapkan warga negara agar dapat mengembangkan tingkah laku demokratis yang terpadu, baik dalam tataran pribadi maupun dalam tataran sosial serta meningkatkan taraf kehidupan yang berbasis demokrasi 
sosial yang produktif. Dalam aplikasinya model pembelajaran kooperatif dilandasi tujuan dan asumsi: (1) Sinergi yang ditingkatkan dalam bentuk kerja sama akan meningkatkan motivasi yang jauh lebih besar daripada dalam bentuk lingkungan kompetisi individual. Perasaan-perasaan saling berhubungan (feelings of connectedness) menghasilkan energi yang positif. (2) Anggota-anggota kelompok kooperatif dapat saling belajar satu dengan lainnya. Setiap siswa akan memperoleh bantuan yang lebih banyak daripada dalam sebuah struktur pembelajaran yang menimbulkan pengucilan antarsatu siswa dengan siswa lainnya. (3) Interaksi antaranggota akan menghasilkan aspek kognitif, semisal kompleksitas. (4) Kerja sama meningkatkan perasaan positif satu dengan lainnya, menghilangkan penyendirian, membangun sebuah hubungan, dan memberikan pandangan positif terhadap orang lain. (5) Kerja sama meningkatkan penghargaan diri, tidak hanya pembelajaran yang berkembang tetapi juga perasaan dihormati dan dihargai oleh orang lain dalam sebuah lingkungan. (6) Siswa yang mengalami dan menjalani tugas, merasa harus bekerja sama sehingga dapat meningkatkan kapasitasnya untuk bekerja sama secara produktif. Dan (7) Siswa dapat belajar dari beberapa latihan untuk meningkatkan kemampuan dirinya (Joyce, 2009: 302).

Model Pembelajaran Kooperatif Cooperative Integrated Reading and Composition (CIRC), model ini pertama kali dibahas oleh Madden, N.A, R.E. Slavin \& R.J. Stevens (1986) dalam tulisannya Cooperative Integrated Reading and Composition: Teacher Manual. Dalam buku ini dibahas secara mendasar langkah-langkah dan bagaimana mengaplikasikan model CIRC ini dalam pembelajaran di kelas. Stevens dan Slavin pada tahun yang sama mengadakan penelitian dengan judul The Effect of Cooperative Integrated Reading and Composition (CIRC) on Academically handicapped and nonhandicapped students' achievement, attitudes, and metacognition in Reading and Writing, dalam Elemetary School Jaurnal (1986, 11, 123-135). Selanjutnya, Hertz-Lazarowitz, R., G. Ivory, \& M. Calderon (1993) mengadakan penelitian dengan judul The Bilingual Cooperative Integrated Reading and Composition (BCIRC) Project in the Ysleta Independent School District: Standarized Test Outcomes. Model pembelajaran kooperatif CIRC adalah model kooperatif yang khusus dibuat untuk pembelajaran bahasa. Hal ini sesuai dengan namanya yang merupakan program komprehensif untuk mengajarkan membaca dan menulis pada kelas sekolah dasar, di samping sekolah yang lebih tinggi (Slavin, 1995: 16). Oleh karena bersifat integratif, maka dalam aplikasinya selalu mengaitkan kedua jenis keterampilan berbahasa tersebut.

Prosedur Model Pembelajaran Kooperatif CIRC adalah: (1) membentuk kelompok dengan anggota 4-5 anak secara heterogen; (2) Pengenalan topik yang akan dibahas; (3) Guru menyajikan pelajaran; (4) Siswa bekerja sama dan berdiskusi, saling membacakan, menemukan ide pokok, dan memberi tanggapan terhadap teks/kliping.; (5) Setiap kelompok mempresentasikan hasil diskusi kelompoknya kepada kelompok lain. Kelompok lain bisa bertanya kepada kelompok yang tampil, dan anggota kelompok yang tampil menjawab secara bergantian; (6) Guru memberi kuis/pertanyaan kepada seluruh kelompok. Kuis dikerjakan secara berkelompok dengan berdiskusi, pada saat menjawab kuis, siswa dapat saling melengkapi dan saling membantu; (7) Guru memberikan penghargaan atas penampilan kelompok dan hasil pengerjaan kuis kelompok; (8) Guru memberikan kuis bersifat individu; dan (9) Guru dan siswa membuat simpulan bersama.

Model Pembelajaran Kooperatif Jigsaw, model ini pertama kali dikenalkan oleh Aronson, dkk. dalam bukunya The Jigsaw classroom (1978). Moskowits, dkk dalam Journal Contemporary Educational Psychology (1985, 10, 104-112) menulis model ini dengan topik Evaluation of Jigsaw, a Cooperative Learning Technique. Lebih lanjut model pembelajaran Jigsaw juga dibahas oleh Mattingly \& Vansickle dalam tulisannya pada Journal Social Education (1991, 55 (6), 392-395) dengan topik Cooperative Learning and Achievement in Social Studies: Jigsaw II. Dalam pembelajaran kooperatif tipe Jigsaw ini, siswa bekerja/belajar dalam kelompok yang heterogen dan beranggotakan 4 sampai 6 orang, yang disebut kelompok asal. Setiap anggota kelompok bertanggung jawab atas penguasaan bagian dari materi belajar yang ditugaskan kepadanya, kemudian mengajarkan bagian tersebut kepada anggota kelompok yang lain. Tiap-tiap anggota kelompok yang mendapat tugas penguasaan bagian materi itu disebut ahli. Keahlian tersebut dapat diperoleh dari menjelaskan bagian materi kepada anggota kelompok menurut kemampuan mereka, atau ditunjuk oleh guru sesuai dengan kemampuan mereka. Anggota dari kelompok yang berbeda dengan topik yang sama (ahli) bertemu untuk berdiskusi antarahli. Mereka dapat saling membantu satu sama lain tentang topik yang ditugaskan dan mendiskusikannya. Selanjutnya, siswa pada kelompok ahli kembali kepada kelompok masing-masing untuk menjelaskan materi tersebut kepada anggota kelompok asal, tentang hasil yang 
dibahas dalam kelompok ahli. Hubungan antara kelompok asal dan kelompok ahli digambarkan Arend. R.I (1997:73) berikut ini.

Kelompok asal (home teams)

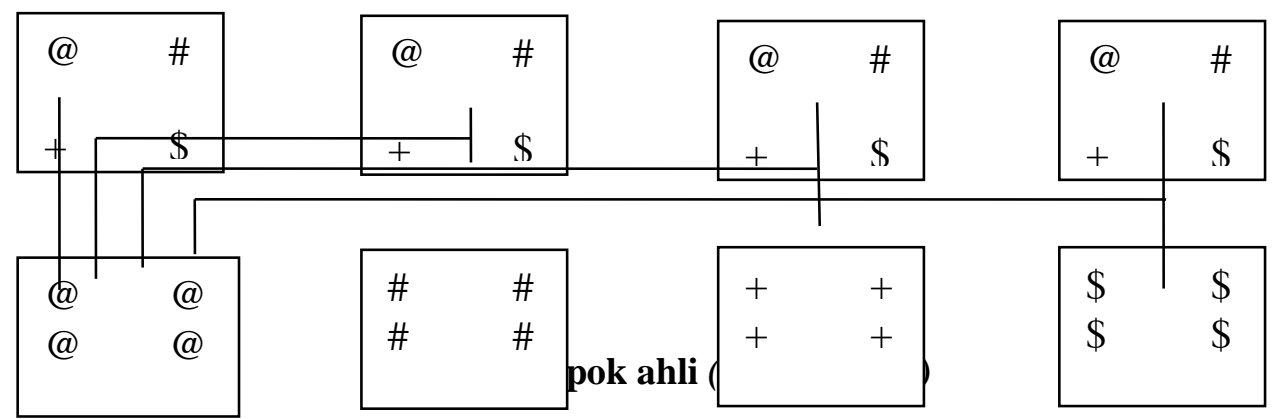

Gambar 1. Hubungan kelompok asal dan kelompok ahli dalam Jigsaw

Adapun prosedur pembelajaran dalam model ini adalah (1) Membentuk kelompok dengan anggota 4-5 anak secara heterogen sebagai kelompok asal (home teams); (2) Pengenalan topik yang akan dibahas; (3) Guru menyajikan pelajaran; (4) Setiap anggota kelompok ditunjuk menjadi ahli dalam bidang tertentu mempelajari materi secara mendalam dan bertanggung jawab terhadap materi bagian masing-masing, berkumpul menjadi kelompok baru yang disebut kelompok ahli (expert teams). Kelompok baru yang terdiiri atas anggota yang ahli (expert) dalam subtopik tertentu, berdiskusi dengan anggota kelompok lain yang memiliki keahlian sama; (5) Setelah materi terkuasai oleh semua anggota kelompok ahli, semua anggota ahli kembali ke kelompok asal untuk menjelaskan (secara bergantian) materi bagian kelompok ahli kepada anggota kelompok asal lainnya; (6) Guru memberi kuis/pertanyaan kepada seluruh kelompok. Kuis dikerjakan secara berkelompok dengan berdiskusi, pada saat menjawab kuis, siswa bisa saling melengkapi dan saling membantu; (7) Guru memberikan penghargaan hasil kuis kelompok; (8) Guru memberikan kuis bersifat individu; dan (9) Guru dan siswa membuat simpulan

Logika merupakan pengetahuan tentang kaidah berpikir. Logika berasal dari bahasa Yunani logos, yang artinya hasil pertimbangan akal pikiran yang diutarakan melalui kata dan dinyatakan dalam bahasa. Logika adalah ilmu bernalar secara tepat. Hal itu berarti bahwa ilmu bernalar berusaha menemukan dan menyatakan kaidah-kaidah sesuai dengan kegiatan berpikir yang dapat dinilai baik atau buruk, benar atau salah, atau masuk akal atau tidak (Leonard, 1967: 11-12). Sementara itu, Copi (1978: 3) menyatakan bahwa logika adalah studi tentang metode dan prinsip yang digunakan untuk membedakan penalaran yang benar dari penalaran yang tidak benar. Konsep bentuk logis adalah inti dari logika. Konsep itu menyatakan bahwa kesahihan sebuah argumen ditentukan oleh bentuk logisnya, bukan oleh isinya.

Sebuah logika terdiri atas dua bagian, yaitu bahasa dan cara penalarannya. Logika berbahasa berkaitan dengan penalaran secara umum dengan menggunakan media bahasa (Hasan Alwi, 2007:680). Logika adalah alat utama untuk mempresentasikan dan bernalar tentang pengetahuan. Secara khusus diperlukan adanya kemampuan untuk bernalar secara logis formal. Keuntungan menggunakan bahasa yang logis formal dalam kecerdasan buatan adalah bahwa bahasa mempresentasikan hal yang terbatas dan secara tepat (Puchta, 2005: 5). Sementara itu, berbahasa pada hakikatnya juga bernalar, artinya bahwa dalam tindak berbahasa juga terlibat strategi yang bersifat lain yang bukan sekadar penggunaan kata-kata. Kejelasan, keruntutan, dan ketepatan penggunaan kata-kata dalam berbahasa berhubungan dengan logika seseorang, kemampuan berpikir logis seseorang. Logika bahasa memiliki tiga aspek utama, yakni berkaitan gramatikal secara umum (morfologi, sintaksis, wacana), semantik, dan metode penalarannya. Oleh karena itu, logika berbahasa sering disebut logika verbal.

Logika berbahasa atau logika verbal adalah kecerdasan kata-kata atau kemampuan untuk menggunakan inti dari cara kerja bahasa dengan jelas. Komponen utama dari kecerdasan ini dijalankan melalui komunikasi dengan cara membaca, menulis, mendengarkan, dan berbicara. Penggunaan kecerdasan ini membantu menghubungkan antara ilmu dan pemahaman yang telah dimiliki dengan informasi-informasi baru serta menjelaskan bagaimana hubungan itu terjadi 
(Bellanca, 2011: 2). Kecerdasan verbal memungkinkan pemikiran seseorang dikomunikasikan dengan pihak lain, sehingga kecerdasan ini memiliki nilai lebih di sekolah.

Secara umum logika berbahasa digolongkan menjadi dua, yaitu logika induktif dan logika deduktif. Logika induktif adalah logika yang bertolak dari yang khusus atau spesifik menuju pada suatu simpulan umum (D’Angelo, 1978: 241-242). Generalisasi, analogi (induktif maupun deklaratif), dan hubungan sebab akibat adalah bagian dari logika induktif. Sedangkan logika deduktif menggunakan berpikir silogisme. Logika ini bertolak dari keadaan secara umum untuk menuju kenyataan-kenyataan secara spesifik. Di dalamnya terdapat premis-premis, yaitu premis mayor (umum) maupun premis minor (khusus). Dalam logika deduktif, premis mayor dikemukakan terlebih dahulu, baru kemudian diikuti dengan premis-premis minor sebagai penjabarannya.

Kemampuan dapat diartikan sebagai kesanggupan, kecakapan, dan kekuatan. Dalam kaitannya dengan logika berbahasa, kemampuan merupakan kecakapan dalam menggunakan penalaran yang berhubungan dengan bahasa. Dengan demikian, kemampuan logika berbahasa adalah kesanggupan seseorang mengungkapkan ide melalui bahasa dan cara penalarannya yang dapat dinyatakan melalui pengukuran-pengukuran tertentu, baik kejelasan, keruntutan, dan ketepatan penggunaan kata-kata dalam berbahasa berhubungan dengan logika seseorang ataupun kemampuan berpikir logis seseorang. Logika bahasa memiliki tiga aspek utama, yakni berkaitan dengan gramatikal secara umum (morfologi, sintaksis), semantik, dan metode penalarannya.

Penelitian yang relevan dengan penelitian ini telah dilakukan oleh beberapa peneliti. Berkaitan dengan model pembelajaran kooperatif dalam bahasa, Sharan dan Shanchar (1988) melakukan eksperimen dengan menggunakan dua kelompok siswa sekolah dasar. Kelompok eksperimen diberikan perlakuan pendekatan pembelajaran bahasa dalam kelas model kooperatif, sedangkan pada kelompok kontrol dengan pendekatan model konvensional. Hasil penelitian ini menunjukkan bahwa siswa yang belajar bahasa dalam kelas dengan model kooperatif, hasilnya jauh lebih bagus dibandingkan dengan siswa yang belajar dalam kelas dengan model konvensional. Pengetahuan dan keterampilan bahasa siswa yang belajar dengan model kooperatif meningkat cukup signifikan apabila dibandingkan dengan sebelum mereka belajar dengan model ini. Sementara yang menggunakan model konvensional peningkatannya kurang memuaskan. Ini berarti model kooperatif sangat efektif untuk pembelajaran bahasa.

Hasil penelitian Ameliana Sapitri (2006), tentang penerapan model pembelajaran kooperatif melalui strategi Raund Table untuk meningkatkan kemampuan membaca pada siswa SD di Jawa Barat, menunjukkan bahwa hasil pembelajaran membaca dengan pembelajaran kooperatif jauh lebih baik dari pada pembelajaran konvensional.

Penelitian tentang model pembelajaran CIRC, yang dilakukan Stevens dan Slavin (1986) maupun Hertz-Lazarowitz, dkk. (1993) dalam penelitian masing-masing menunjukkan bahwa model pembelajaran kooperatif model $C I R C$, sangat unggul untuk meningkatkan kemampuan membaca dan menulis.

Demikian juga, model pembelajaran Jigsaw II, Mattingly dan Vansickle dalam review penelitiannya pada Journal Social Education (1991, 55 (6), 392-395) dengan topik Cooperative Learning and Achievement in Social Studies: Jigsaw II, memberikan gambaran bahwa pembelajaran kooperatif model jigsaw II sangat efektif untuk meningkatkan ilmu sosial dalam diri siswa.

Dari beberapa hasil penelitian tentang model pembelajaran kooperatif di atas, dapat disimpulkan bahwa model pembelajaran kooperatif sangat baik untuk diterapkan dalam rangka meningkatkan hasil pembelajaran keterampilan membaca.

Sementara itu, berkait dengan kemampuan logika berbahasa, beberapa penelitian yang relevan adalah Khairil Ansari (1997) dalam penelitiannya yang berjudul "Pengaruh Pendekatan Pembelajaran dan Latar Belakang terhadap Kemampuan Analogi Verbal" menyimpulkan bahwa kemampuan analogi verbal mahasiswa yang belajar dengan pembelajaran terpadu lebih baik daripada yang belajar dengan pembelajaran terpisah. Lebih lanjut, hasil penelitian juga menggambarkan bahwa pembelajaran terpadu lebih berpengaruh dibandingkan dengan pembelajaran terpisah dalam meningkatkan kemampuan analogi verbal mahasiswa. Dengan demikian, dapat dikatakan bahwa kemampuan verbal dapat ditingkatkan dengan pembelajaran terpadu.

Berpijak dari kajian-kajian teori, jurnal-jurnal ilmiah, dan beberapa penelitian yang relevan di atas maka penelitian ini memiliki kebaruan dalam aspek aplikasi, adaptasi, dan komparasi model pembelajaran inovatif model pembelajaran kooperatif: CIRC dan Jigsaw, yang dikaitkan dengan 
kemampuan logika berbahasa siswa dalam rangka meningkatkan keterampilan membaca siswa sekolah dasar.

\section{METODE PENELITIAN}

Metode yang digunakan dalam penelitian ini adalah penelitian eksperimen. Penelitian eksperimen berpijak dari investigasi hubungan sebab akibat yang mungkin timbul atas pemberian kondisi-kondisi perlakuan dan membandingkannya antara kelompok yang diberikan perlakuan dan kelompok pembanding atau kontrol.

Penelitian eksperimental pada umumnya memiliki tiga karakteristik dasar, yakni (1) suatu variabel bebas dimanipulasi; (2) semua variabel lainnya, kecuali variabel bebas, dipertahankan tetap; dan (3) pengaruh manipulasi variabel bebas terhadap variabel terikat diamati (Ary, D, L.C. Jacobs, \& A. Razaveih, 2005: 338).

Dalam penelitian ini ditentukan variabel yang dimanipulasi adalah dua variabel bebas, yaitu: variabel model pembelajaran kooperatif dijabarkan menjadi dua, yaitu model pembelajaran kooperatif $C I R$ dan, model pembelajaran kooperatif Jigsaw, sebagai variabel ekperimental. Variabel bebas yang kedua yang dikontrol dan ikut mempengaruhi variabel terikat adalah kemampuan logika berbahasa sebagai variabel atributif, yang dibedakan dalam kemampuan logika bahasa tinggi dan kemampuan logika bahasa rendah. Sedangkan variabel terikatnya adalah keterampilan membaca.

Adapun rancangan yang digunakan dalam penelitian ini adalah rancangan faktorial $2 \times 2$. Penentuan disain merujuk Ary.D, Lucy Cheser Jacobs, dan Asghar Razavieh (2005: 391). Pola rancangan faktorial 3 × 2 ini tampak pada gambar berikut ini.

\begin{tabular}{|c|c|c|c|}
\cline { 3 - 4 } \multicolumn{2}{c|}{} & \multicolumn{2}{c|}{$\mathrm{B}$} \\
\cline { 3 - 4 } \multicolumn{2}{c|}{} & $\mathrm{B}-1$ & $\mathrm{~B}-2$ \\
\cline { 3 - 4 } $\mathrm{A}$ & $\mathrm{A}-1$ & $\mathrm{~A}_{1} \mathrm{~B}_{1}$ & $\mathrm{~A}_{1} \mathrm{~B}_{2}$ \\
\cline { 2 - 4 } & $\mathrm{A}-2$ & $\mathrm{~A}_{2} \mathrm{~B}_{1}$ & $\mathrm{~A}_{2} \mathrm{~B}_{2}$ \\
\hline
\end{tabular}

\section{Gambar 2 : Disain Faktorial Penelitian}

Keterangan:

A $=$ Model Pembelajaran Kooperatif

$\mathrm{B} \quad=$ Kemampuan Logika Berbahasa

A-1 = Model Pembelajaran Kooperatif $C I R C$

A-2 = Model Pembelajaran Kooperatif Jigsaw

B-1 = Kemampuan Logika Berbahasa Tinggi

B-2 = Kemampuan Logika Berbahasa Rendah

$\mathrm{A}_{1} \mathrm{~B}_{1}=$ kumpulan nilai keterampilan membaca kelompok $C I R C$ - kemampuan logika bahasa tinggi

$\mathrm{A}_{1} \mathrm{~B}_{2}=$ kumpulan nilai keterampilan membaca kelompok Jigsaw - kemampuan logika bahasa rendah

$\mathrm{A}_{2} \mathrm{~B}_{1}=$ kumpulan nilai keterampilan membaca kelompok STAD-kemampuan logika bahasa tinggi

$\mathrm{A}_{2} \mathrm{~B}_{2}=$ kumpulan nilai keterampilan membaca kelompok $C I R C$ - kemampuan logika bahasa rendah

Penelitian ini dilaksanakan di Sekolah Dasar pada kelas 5 Dinas Pendidikan Nasional Provinsi Jawa Tengah pada semester gasal tahun pelajaran 2011/2012, yang sekaligus menjadi populasi. Sedangkan sampel terpilih sebanyak 8 SD untuk eksperimen.Teknik sampling yang digunakan ialah multi stage area random sampling (area provinsi, area Kabupaten/kota dan area kecamatan: Gugus Sekolah/Daerah Binaan). Dari 35 kabupaten/kota di Jawa Tengah dipilih secara acak empat kabupaten/kota, kemudian dari empat kabupaten terpilih masing-masing diambil secara acak dua kecamatan, selanjutnya tiap-tiap kecamatan diambil secara acak satu SD. SD terpilih setiap kecamatan dalam tiap-tiap kabupaten merupakan SD penelitian, sehingga jumlah SD penelitian yang didapatkan adalah 8 sekolah dasar yang tersebar di 4 kabupaten dan 8 kecamatan.

Empat kabupaten/kota terpilih adalah Kabupaten Kudus, Kota Semarang, Kabupaten Magelang, dan Kabupaten Karanganyar. Di Kabupaten Kudus terpilih dua kecamatan, yaitu Kec. Kota dengan SD sampel SD Muhammadiyah 1Kudus dan Kecamatan Bae dengan SD sampel SD Bae 01. Di Kota Semarang terpilih dua kecamatan, yaitu Kecamatan Gajah Mungkur dengan SD sampel SD Petompon 07 dan Kecamatan Pedurungan dengan SD sampel SD Pedurungan Lor 01. Di 
kabupaten Magelang terpilih dua kecamatan, yaitu Kecamatan Mungkid dengan SD sampel SD Mungkid 02 dan Kecamatan Mertoyudan dengan SD sampel SD Mertoyudan 2. Di Kabupaten Karanganyar terpilih dua kecamatan, yaitu Kecamatan Gondangrejo dengan SD sampel SD 01 Wonorejo dan Kecamatan Karanganyar dengan SD sampel SD 01 Pompongan. Dari delapan SD yang menjadi sampel penelitian, 4 sekolah (kelas) untuk sampel perlakuan model pembelajaran kooperatif jenis CIRC dan 4 sekolah (kelas) untuk sampel perlakuan model pembelajaran jenis Jigsaw.

Instrumen yang digunakan untuk mengumpulkan data keterampilan membaca bahasa Indonesia ini berbentuk tes keterampilan membaca. Tes yang dipakai sebanyak 50 soal yang berupa tes objektif berbentuk pilihan ganda dengan empat alternatif jawaban (A, B ,C , dan D). Instrumen yang digunakan untuk mengumpulkan data kemampuan logika berbahasa berbentuk tes. Tes kemampuan logika berbahasa sebanyak 40 butir. Kedua tes tersebuat sudah diuji kesahihan, keterandalannya, tingkat kesukaran, dan uji beda.

\section{HASIL PENELITIAN DAN PEMBAHASAN}

Data yang berhasil dikumpulkan berkait dengan keterampilan membaca untuk kelompok siswa yang mengikuti pembelajaran model CIRC (A1) menunjukkan bahwa nilai tertinggi keterampilan membaca sebesar 98, nilai terendah sebesar 56, rentang nilai (range) 56 - 98, mean sebesar 79,4590, modus (Mo) sebesar 80, median (Me) sebesar 80, dan simpangan baku (s) sebesar 11,4763. Kelompok siswa yang mengikuti pembelajaran model Jigsaw (A2) menunjukkan bahwa nilai tertinggi keterampilan membaca sebesar 98, nilai terendah sebesar 54, rentang nilai (range) 54 98, mean sebesar 76,7581, modus (Mo) sebesar 80, median (me) sebesar 78, dan simpangan baku (s) sebesar 10,9622.

Data yang berhasil dikumpulkan berkait dengan keterampilan membaca untuk kelompok siswa yang memiliki kemampuan logika bahasa tinggi (B1) menunjukkan nilai tertinggi keterampilan membaca sebesar 98, nilai terendah sebesar 62, rentang nilai (range) 62-98, mean sebesar 82,1778, modus (Mo) sebesar 80, median (Me) sebesar 82, dan simpangan baku (s) sebesar 10,1715. Kelompok siswa yang memiliki kemampuan logika bahasa rendah (B2) menunjukkan bahwa nilai tertinggi keterampilan membaca sebesar 92, nilai terendah sebesar 54, rentang nilai (range) 54-92, mean sebesar 73,0109, modus (Mo) sebesar 74, median (Me) sebesar 74, dan simpangan baku (s) sebesar 10,1637.

Data yang berhasil dikumpulkan berkait dengan keterampilan membaca untuk kelompok siswa yang mengikuti model pembelajaran CIRC dan memiliki kemampuan logika tinggi (A1B1) menunjukkan bahwa nilai tertinggi keterampilan membaca sebesar 98, terendah sebesar 64, rentang nilai (range) 64-98, mean sebesar 86,3793, modus (Mo) sebesar 90, median (Me) sebesar 88, dan simpangan baku (s) sebesar 8,7094. Kelompok siswa yang mengikuti model pembelajaran CIRC dan memiliki kemampuan logika rendah (A1B2) menunjukkan nilai tertinggi sebesar 92, nilai terendah sebesar 56, rentang nilai (range) 56-92, mean 73,1875, modus (Mo) sebesar 80, median (Me) sebesar 74, dan simpangan baku (s) sebesar 9,9355.

Data yang berhasil dikumpulkan berkait dengan keterampilan membaca untuk kelompok siswa yang mengikuti model pembelajaran Jigsaw dan memiliki kemampuan logika tinggi (A2B1) nilai tertinggi keterampilan membaca 98, terendah 62, rentang nilai (range) 62-98, mean 80,2540, modus (Mo) 80, median (Me) 80, dan simpangan baku (s) 10,2893. Kelompok siswa yang mengikuti model pembelajaran Jigsaw dan memiliki kemampuan logika rendah (A2B2) menunjukkan nilai tertinggi keterampilan membaca 92, terendah 54, rentang nilai (range) 54-92, mean sebesar 73,1475, modus (Mo) sebesar 80, median (Me) sebesar 74, dan simpangan baku (s) sebesar 10,5291.

Tabel 1

Rangkuman Data Nilai Keterampilan Menulis

\begin{tabular}{|c|c|c|c|c|}
\hline \multirow{2}{*}{\multicolumn{2}{|c|}{$\begin{array}{l}\text { MODEL PEMBELAJARAN } \\
\text { (A) }\end{array}$}} & \multicolumn{2}{|c|}{$\begin{array}{c}\text { KEMAMPUAN LOGIKA } \\
\text { BAHASA (B) }\end{array}$} & \multirow[t]{2}{*}{ Jumlah } \\
\hline & & Tinggi (B1) & Rendah (B2) & \\
\hline \multirow{5}{*}{$\begin{array}{c}\text { CIRC } \\
\text { (A1) }\end{array}$} & $\mathrm{N}$ & 58 & 64 & 122 \\
\hline & $\sum \mathrm{X}$ & 5010 & 4684 & 9694 \\
\hline & Min. & 64 & 56 & 56 \\
\hline & Max. & 98 & 92 & 98 \\
\hline & $\bar{X}$ & 86.3793 & 73.1875 & 79.4590 \\
\hline
\end{tabular}




\begin{tabular}{|c|c|c|c|c|}
\hline & Mo & 90 & 80 & 80 \\
\hline & $\mathrm{Me}$ & 88 & 74 & 80 \\
\hline & $S$ & 8.7093972 & 9.935534 & 11.47628 \\
\hline & Var. & 75.8536 & 100.2817 & 131.7049 \\
\hline & Range & 34 & 36 & 42 \\
\hline & $\sum \mathrm{X}^{2}$ & 437084 & 349128 & 786212 \\
\hline \multirow{11}{*}{$\begin{array}{c}\text { JIGSAW } \\
\text { (A2) }\end{array}$} & $\mathrm{N}$ & 63 & 61 & 124 \\
\hline & $\sum X$ & 5056 & 4462 & 9518 \\
\hline & Min. & 62 & 54 & 54 \\
\hline & Max. & 98 & 92 & 98 \\
\hline & $\bar{X}$ & 80.2540 & 73.1475 & 76.7581 \\
\hline & Mo & 80 & 80 & 80 \\
\hline & $\mathrm{Me}$ & 80 & 74 & 78 \\
\hline & $S$ & 10.289312 & 10.529065 & 10.962145 \\
\hline & Var. & 105.8699 & 110.8612 & 120.1686 \\
\hline & Range & 36 & 38 & 44 \\
\hline & $\sum \mathrm{X}^{2}$ & 412328 & 333036 & 745364 \\
\hline
\end{tabular}

\section{PENUTUP}

Dari hasil penelitian diperoleh simpulan (1) ada perbedaan keterampilan membaca bahasa Indonesia antara kelompok siswa yang belajar dengan model pembelajaran kooperatif jenis CIRC dan yang belajar dengan model pembelajaran kooperatif jenis Jigsaw. Perbedaan itu berupa kelompok siswa yang belajar dengan model pembelajaran CIRC lebih efektif daripada yang belajar dengan Jigsaw (2) Ada perbedaan keterampilan membaca bahasa Indonesia antara kelompok siswa yang memiliki kemampuan logika berbahasa yang tinggi dan siswa yang memiliki kemampuan logika berbahasa yang rendah.(3) Ada interaksi antara penggunaan jenis model pembelajaran kooperatif dan kemampuan logika berbahasa dalam mempengaruhi keterampilan membaca bahasa Indonesia siswa. Beberapa interaksi dapat dijelaskan berikut ini: (a) Dalam pembelajaran keterampilan membaca, penggunaan model pembelajaran CIRC lebih efektif digunakan untuk siswa yang memiliki kemampuan logika tinggi dibandingkan dengan siswa yang memiliki logika bahasa rendah; (b) Dalam pembelajaran keterampilan membaca, penggunaan model pembelajaran Jigsaw lebih efektif digunakan untuk siswa yang memiliki kemampuan logika tinggi dibandingkan dengan siswa yang memiliki logika bahasa rendah; (c) Dalam pembelajaran keterampilan membaca siswa yang memiliki kemampuan logika tinggi, penggunaan model pembelajaran CIRC lebih efektif dibandingkan dengan model pembelajaran Jigsaw; dan (d) Dalam pembelajaran keterampilan membaca pada siswa yang memiliki kemampuan logika rendah, penggunaan ketiga model pembelajaran kooperatif : CIRC maupun Jigsaw tidak menunjukkan perbedaan efektivitas.

\section{DAFTAR PUSTAKA}

A. Chaedar Alwasilah. 2000. "Membenahi Kuliah MKDU Bahasa Indonesia di Perguruan Tinggi". Dalam Kaswanti Purwa (Ed). Kajian Serba Linguistik untuk Anton M. Moeliono Pereksa Bahasa. Halaman 677- 693. Jakarta: BPK Gunung Mulia dalam kerja sama dengan Universitas Katolik Indonesia Atma Jaya.

Ameliana Sapitri. 2006. Model Pengembangan Pembelajaran Kooperatif melalui Strategi Round Table untuk Meningkatkan Kemampuan Membaca.Tersedia di http://garuda.dikti.go.id/jurnal/detil/id/7:5128/q/penelitian\%20. Diunduh 2 Juni 2010.

Anita Lie. 2008. Cooperative Learning, Mempraktikkan Cooperative Learning di Ruang-ruang Kelas . Jakarta: Gransindo.

Arends, R.I. 1997. Classroom Instruction and Management. New York: McGraw-Hill. 
Aronson, E., dkk. 1978. The Jigsaw Classroom. Beverly Hills, CA: Sage Publication, Inc.

Ary, D, L.C. Jacobs, \& A. Razaveih. 1985. Pengantar Penelitian dalam Pendidikan. Diterjemahkan oleh Arief Furchan. Yogyakarta: Pustaka Pelajar.

Bell, T. 1998. "Extensive Reading: Why? And How?". The Internet TESL Journal, Vol. IV. No. 12, December 1998. Tersedia di http://iteslj.org/Articles/Bell-Reading.html. Diunduh 3 Juni 2010.

Bell, T \& J. Cambell. 1997. "Promoting Good Reading Habits Part 2: The Role of Libraries" Network 2/4: 26-35. Tersedia di http://iteslj.org/ Diunduh 17 Juli 2010.

Bellanca, James. 2011. 200 + Strategi dan Proyek Pembelajaran Aktif untuk Melibatkan Kecerdasan Siswa. Diterjemahkan oleh Siti Mahyuni. Jakarta: PT Indeks.

Brown, H.D. 2004. Language Assessment Principles and Classroom Practices. San Francisco: Longman.

Burns, P.C, D. Betty. \& E.P.Ross. 1996. Teaching Reading in today's Elementary Schools. Chicago: Rand Mc. Nally College Publising Company.

Copi, I.M. 1978. Introduction to Logic. New York: Macmillan Publishing Co. Inc.

Crawley, S.J \& L. Mountain. 1995. Strategies for Guiding Content Reading. Boston: Allyn and Bacon.

D’Angelo, F.J. 1980. Process and Thought in Composition. Cambridge: Winthrop Publishers Co. Int.

Farida Rahim. 2003. Pengajaran Membaca di Kelas IV Sekolah Dasar 08 Padang. Disertasi Universitas Negeri Malang.

Frantz, L.J. 1979. The Effect of Student Teams Achievement Approach in Reading on Peer Attitudes. Old Dominion University.

Harimurti Kridalaksana. 2009. Kamus Linguistik (Edisi Keempat-Cetakan Kedua). Jakarta : PT Gramedia.

Hertz-Lazarowitz, R., G. Ivory, \& M. Calderon. 1993. The Bilingual Cooperative Integrated Reading and Composition (BCIRC) Project in the Ysleta Independent School District: Standardized Test Outcomes. Baltimore, MD: John Hopkins University Center for Research on Effective Schooling for Disadvantaged Student.

Iskandarwassid dan Dadang Sunendar. 2009. Strategi Pembelajaran Bahasa. Bandung: Kerja sama Sekolah Pascasarjana UPI dan Remaja Rosdakarya.

Imam Syafei. 1999. Pengajaran Membaca di Kelas-kelas Awal Sekolah Dasar. Malang: Universitas Negeri Malang.

Johnson, R.T. \& D.W. Johnson. 2006. What is Cooperative Learning? Minneapolis, Minnesota: The Cooperative Learning Center at the University of Minnesota.

Joyce, B., M. Weil, \& E. Calhoun. 2009. Models of Teaching (8th ed.). Boston: Allyn Bacon/Pearson.

Khairil Ansari, 1997. Pengaruh Pendekatan Pembelajaran dan Latar Belakang terhadap Kemampuan Analogi Verbal. Disertasi. UNJ.

Kirby, J.R., 2007. "Reading Comprehension: Its Nature and Development." Encyclopedia of Language and Literacy Development, halaman 1-8. London, ON: Canadian Language and Literacy Research Network. Tersedia di http://www.literacyencyclopedia.ca/pdfs/topic.php?topld=227

Klein, M.L, S. Peterson, \& L. Semingston. 1991. Teaching Reading in the Elementary Grades. Boston: Allyn and Bacon.

Leonard, S. H.. 1967. Principles of Reasoning: An Introduction to Logic, Methodology and The Theory of Sign. New York: McMillan Publishing Inc. 
Madden, N.A, R.E. Slavin \& R.J. Stevens. 1986. Cooperative Integrated Reading and Composition: Teacher's Manual. Baltimore: John Hopkins University, Center for Research on Elementary

Mattingly, R.M. \& R.L. Vansickle 1991. "Cooperative Learning and Achievement in Social Studies: Jigsaw II”. Journal Social Education, 55 (6), 392-395.

Moskowitz,J.M., dkk. 1985. "Evaluation of Jigsaw, a Cooperative Learning Tcchnique". Contemporary Educational Psychology, Vol. 10, 104-112.

Mulyanto Sumardi. 2000. "Pengajaran Bahasa Indonesia yang Efektif dan Efisien di SLTA". Dalam Kaswanti Purwa (Ed). Kajian Serba Linguistik untuk Anton M. Moeliono Pereksa Bahasa. Halaman 787 - 792. Jakarta: BPK Gunung Mulia dalam kerja sama dengan Universitas Katolik Indonesia Atma Jaya.

National Reading Panel. 2000. Report of National Reading Panel Teaching Children to Read: An Evidence-Base Assessment of the Scientific Research Literature on Reading and Its Implications for Reading Instruction. Rockville, MD: National Institute of Child Health and Human Development.

Pessley, M. 2001. Comprehension Instruction: What Makes Sense Now, What Might Make Sense Soon. International Reading Association, Inc. Tersedia di Reading Online, www.readingline.org. Diunduh 25 Juni 2010.

Puchta, H. \& M. Rinvolucri. 2005. Multiple Intelligences in ELT: Exercises for secondary and adult students. Helping Languages. Tersedia di http:// www.helblinglanguages.com. Diunduh pada 10 Juni 2010.

Slavin, R.E. 1995. Cooperative Learning: Theory, Research and Practice. London: Allyn \& Bacon.

Stevens, R.J.\& R.E. Slavin. 1986. "The Effect of Cooperative Integrated Reading and Composition (CIRC) on Academically handicapped and nonhandicapped students' achievement, attitudes, and metacognition in Reading and Writing", dalam Elementary School Journal (1986, 11, 123 $135)$. 